\title{
Mediestream runder tre millioner radio- og tv-udsendelser
}

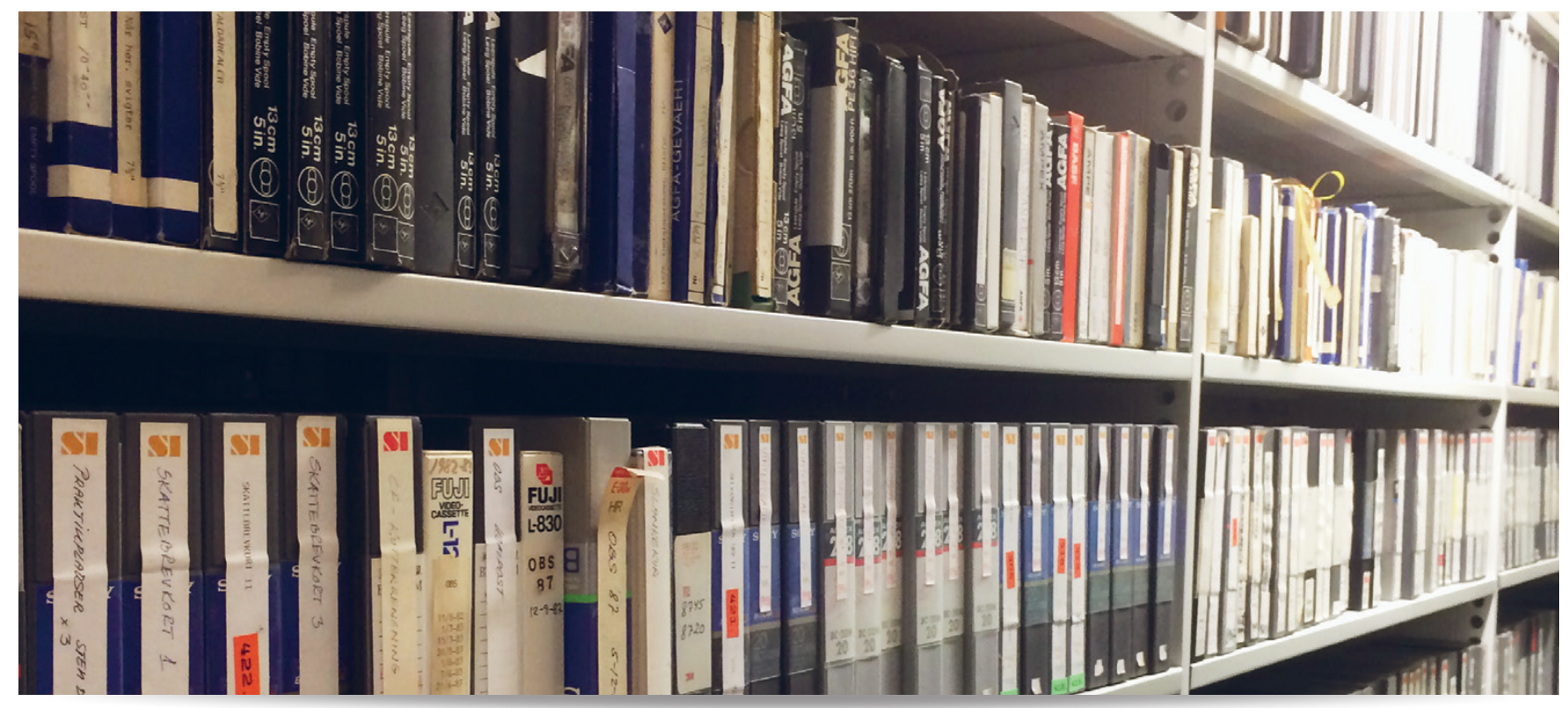

Sådan så et velassorteret AV- og mediebibliotek ud for ikke så længe siden. Foto: KB

Fik du heller ikke lige set DR's indenrigsmagasin Ekko den 17. maj 1963? Nej, vel. Så kan det 30-minutters lange sort-hvide tv-program om "danskernes nye rejsevaner" og et indslag om Civilforsvarets aktuelle pjece "Hvis krigen kommer", streames på platformen Mediestream. Programmet er tilmed samlingens ældste.

Det Kgl. Bibliotek har den nationale forpligtelse til at indsamle og bevare radio og tv - som udgør nogle af de allervæsentligste kilder til samtidshistorien - til glæde for brugere nu og i fremtiden. Mediestream.dk, der rummer en stor del af Det Kgl. Biblioteks digitale radio/tv-arkiv, har netop rundet tre millioner udsendelser.

Mediestream giver adgang til udsendelser fra 80 forskellige radio- og tv-kanaler, lige fra landsdækkende DR1, TV-2 og P3 til mindre kendte lokalstationer som kanalen EfterskoleTv.
Dagligt tilføjes godt 1.500 udsendelser til Mediestream. Dette sker ved fuldautomatisk opklipning af de ca. 600 timers radio- og tv-sendeflade, som hvert døgn nedtages via en tilslutning til data-overvågningsfirmaet Cibicoms digitale sendenet.

De mange timers sendeflade gemmes uændret i bibliotekets bevaringssystemer. Med udgangspunkt i programoplysninger og udsendelsestidspunkter leveret af Ritzau og Gallup sammenkobles metadata om hver enkelt udsendelse, og der genereres en formidlingskopi i lavere opløsning. Metadata og formidlingskopi gøres tilgængelig i Mediestream. Alle udsendelser kan fremsøges og afspilles cirka tre uger efter udsendelsestidspunktet.

Tredobling af mængden af materiale I 1987 fik Statsbiblioteket, nu Det Kgl. Bibliotek, til opgave at oprette et nationalt arkiv for danske radio- og

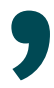

Hvert døgn kommer der 1.500 nye udsendelser til, som kan bruges til undervisning og forskning. 
tv-udsendelser, og Statens Mediesamling blev etableret. Vi har tidligere fortalt, hvad der skete i de følgende år (DF Revy 3, 2008; DF Revy 3, 2016). Her kan man læse om udviklingen fra et aftale-baseret arkiv til pligtaflevering, fra analog til digital indsamling, og om ændringerne fra ingen adgang over dvd-udlån og til lancering i Mediestream i 2013 med cirka én million udsendelser. I løbet er årene er mængden af materiale tredoblet. Brugen af Mediestream har siden 2014 ligget nogenlunde stabilt på ca. 500.000 årlige besøg.

\section{Håndholdt proces \\ Mediestream indeholder - i overens- stemmelse med bibliotekets indsam- lingspligt - landsdækkende radio- og fjernsynsstationer, der har en væsent- lig egenproduktion og en vis udbre- delse i Danmark, hvad angår seer-og lyttertal. Derudover findes et selektivt udvalg af regionale og lokale radio- og fjernsynskanaler samt af landsdæk- kende radio- og fjernsynskanaler, der i overvejende grad udsender allerede udgivet musik og programindhold af udenlandsk oprindelse.}

Ud over tilvæksten af de nyeste udsendelser bliver der også løbende tilføjet historiske udsendelser fra bibliotekets båndarkiver fra før 2006. Dette er en meget håndholdt proces, fordi udsendelserne først skal digitaliseres, klippes, uploades og kobles til metadata, men på en god måned tilgængeliggøres op mod 100 historiske tv-udsendelser.

I løbet af 2021 forventer biblioteket desuden at begynde at publicere ældre digitaliserede radio-udsendelser. I første omgang bliver der tale om udsendelser, der er blevet bestilt til digitalisering af brugere. Hvis man ikke kan finde en udsendelse i Mediestream, er det sandsynligvis, fordi den ikke er blevet digitaliseret endnu, og så kan man bestille den. Det er dog ikke alle udsendelser, der kan bestilles, for biblioteket har kun en fuldstændig samling fra 80'erne og frem.

Før det er samlingen mere sporadisk, idet den består af mindre særsam-

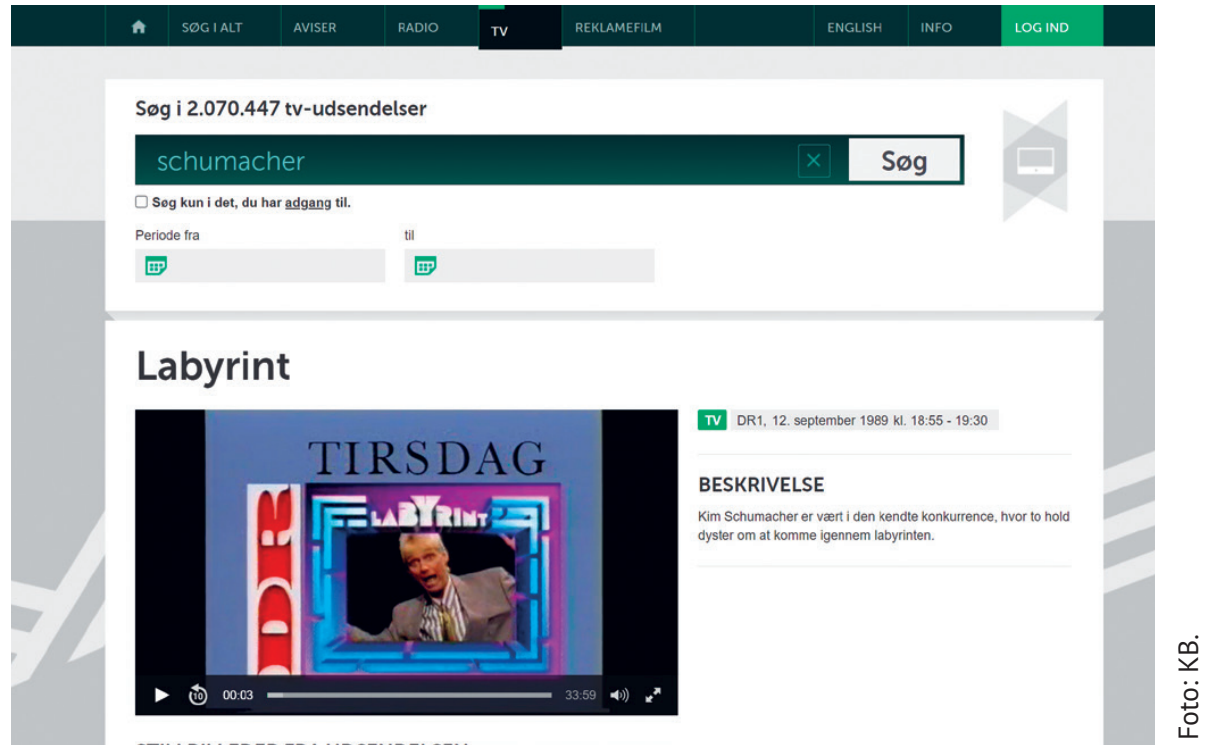

Mediehistorie. Quizprogrammet Labyrint fra DR med værten Kim Schumacher er et af de over to millioner tv-programmer, der kan studeres nøjere på Mediestream.

linger optaget på bånd af institutioner og privatpersoner og senere doneret til biblioteket. Det er heller ikke alt nyere materiale, der er i Mediestream endnu, heller ikke selv om det allerede er digitalt. Det gælder især for lokal- og regionalstationer, der skal forberedes til publicering på en mere håndholdt måde. Det skyldes, at hver af stationerne selv har afleveret materialet til biblioteket på forskellige måder.

\section{Samarbejde med DR}

DR har siden Statsradiofoniens (forløberen for DR) etablering i 1925 haft et arkiv og estimerer, at ca. 30 procent af alt produceret og udsendt radio/tv er bevaret. I forhold til DR-materiale er DR og Det Kgl. Biblioteks arkiver i stort omfang overlappende, men de er også gensidigt supplerende. Imidlertid har de to institutioner både forskellige brugergrupper og forskellige services.

\section{DR servicerer den brede befolkning} på DRTV og DR LYD på dr.dk med udvalgte aktuelle udsendelser, der er tilgængelige i en kort periode i en høj kvalitet. Desuden servicerer DR professionelle og kommercielle kunder via DR Arkivsalg.

Det Kgl. Biblioteks servicerer derimod først og fremmest forskere og studerende, og i en lavere kvalitet egnet til dokumentation. DR og Det Kgl. Bibliotek har etableret et samarbejde således, at udsendelser, der ikke haves i den ene institution, af medarbejderne kan rekvireres i den anden institution. Sådan kan alle brugertyper serviceres bedst muligt. De to institutioner samarbejder også for at sikre bedst mulig udnyttelse af begrænsede digitaliseringsmidler, således at indhold, der findes på fysiske av-bånd, kun digitaliseres én gang, også selv om det pågældende indhold findes på bånd i begge institutioner.

DR og Det Kgl. Bibliotek fik i 2018 af Kulturministeriet til opgave at gennemføre et udredningsarbejde med henblik på at redegøre for, hvordan biblioteket kunne tilgængeliggøre DR's arkivudsendelser for en bredere målgruppe, for eksempel alle udsendelser ældre end 10 år til hele Danmarks befolkning. Udredningen viste, at der vil være betydelige synergieffekter ved at lade biblioteket stå for en sådan tilgængeliggørelse, da der er et stort overlap med bibliotekets eksisterende opgaver. I øjeblikket afventer vi, at politikerne får forhandlet en ny medieaftale på plads, og om der bliver afsat rammer til at arbejde videre med disse planer.

Ditte Laursen er ph.d.og afdelingsleder ved Digital Kulturarv, Det Kgl. Bibliotek. 


\section{De har adgang til Mediestream}

Studerende og ansatte ved seks danske universiteter (CBS, KU, RUC, SDU, AU, AAU) har online adgang til materialet, ligesom arkitektskolen Aarhus og Danmarks Medie- og Journalisthøjskole også har købt online adgang.

Licensindtægterne, som institutionerne betaler til biblioteket, benytter biblioteket til at betale rettighedshaverne via en aftale med Copydan AVU. Museer har via en aftale med Slots- og Kulturstyrelsen og Copydan AVU også mulighed for at tilgå materialet med henblik på at kunne hente udsendelser til brug i udstillinger og undervisning. Der er i øvrigt fri adgang til udsendelserne for alle ved fremmøde på Det Kgl. Bibliotek og Det Danske Filminstitut.

Et lille udvalg af udsendelserne findes desuden på mitcfu.dk (Centre for Undervisningsmidler) til elever og ansatte på folkeskoler og på de korte og mellemlange videregående uddannelser.

$-d l$

\section{Ministeren tager imod}

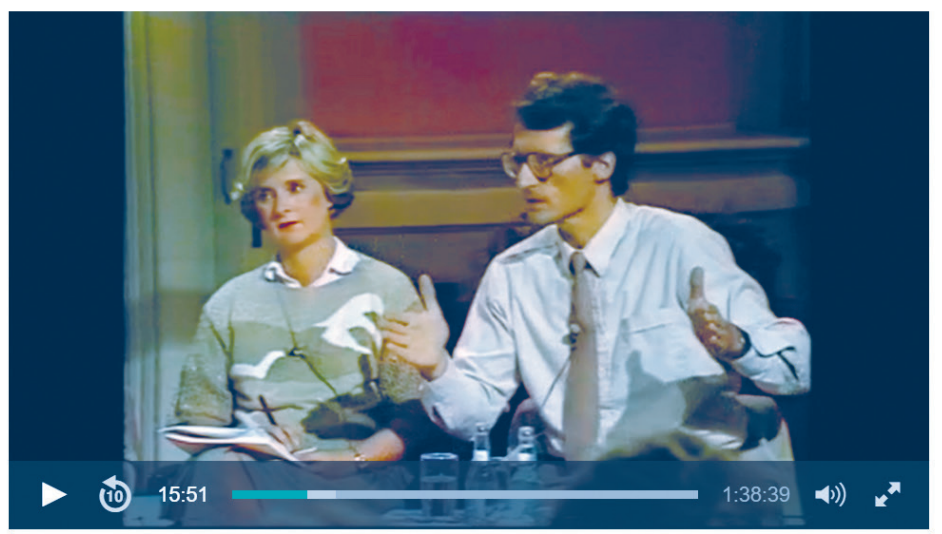

DR, 3. september 1984 kl. 21:45 - 23:23

\section{BESKRIVELSE}

En TV-aktuelt om arbejdsmarkedet og de unge. Har vi en chance? Det spørger mange unge om, når de står foran et uddannelsesforløb, eller når de efter en uddannelse skal finde et arbejde. Er uddannelserne gode nok - er de i tilstrækkeligt omfang frit tilgængelige, eller brude omvendt styres i mere sikre baner? Har vi point og karakterræs og hvor store er chancherne for de mange, der ikke ønsker eller magter de lange uddannelsesforløb. Disse spørgsmål og mange flere vil ca. 35 unge stille til undervisningsminister Bertel Haarder og arbejdsminister Grethe Fenger Mølleri en direkte konfrontation.

Programmerne på Mediestream er forsynet med en kort syntese af indholdet. Her er det

"Ministeren tager imod" fra september 1984 med to unge ministre fra Schlüterregeringen.

\section{Særlig service til forskere}

Mediestream opfylder ikke alle undervisnings- og forskningsbehov, og især forskere kan have brug for radio/tv på andre måder end streaming. Derfor har biblioteket parallelt med Mediestream Offline adgang udviklet enkelte services målrettet forskere.

For eksempel kan forskere med en konkret forskningsopgave og et dokumenteret særligt behov for at have materialet som en fil i stedet for som stream under visse betingelser få adgang til at downloade radio- og tv-udsendelser i høj kvalitet fra Mediestream eller få tilsendt filen. Et sådan særligt behov kan eksempelvis være at have adgang til materialet offline, nærstudier af en tv-udsendelse i høj kvalitet eller at kunne transskribere via software, der afspiller filen. Det er en paragraf i ophavsretsloven, der giver mulighed for eksemplarfremstilling af radio, tv og webmateriale særligt til forskning (§ 16a Datasæt, stk. 3).

Hvis der er tale om større mængder af materiale til brug for tekst- og datamining, kan biblioteket også generere og udlevere et datasæt. På den baggrund har en forsker eksempelvis for nylig fået udleveret kl.18.30 DR1 nyhedsudsendelsen fra alle ugedage i 2018, inklusiv DVB-teletekst, DVB-undertekster og DVB-undertekster for hørehæmmede. Disse data skulle bruges til forskellige indholdsanalyser, som identifikation af interviewpersoner og emner i nyhedsfortællingerne. Forskningsinstitutionen er forpligtet til at slette materialet Nye brugsbehov, når forskningsprojektet er slut.

Lovgrundlaget for denne udleveringsservice har været til stede, siden den nuværende ophavsretslov blev skabt, men det er først i forbindelse med udbredelsen af digital humaniora og brugervenlige værktøjer til processering, at biblioteket har etableret servicen, der aktuelt benyttes af 5-10 forskningsprojekter årligt. Det er således endnu et eksempel på, at biblioteket løbende må tilpasse sig skiftende betingelser fra omverdenen samtidig med en udforskning af de tekniske muligheder og juridiske rammer med henblik på at transformere sine tjenester til nye brugsbehov. $-d l$ 